\title{
ENVIRONMENTRAL STUDIES IN THE QAUMARUJUK AND AGFARDLIKAVSÂ FJORDS, UMANAK DISTRICT, CENTRAL WEST GREENLAND
}

\author{
Jan Bondam and Gert Asmund
}

Early in 1972 Greenex A/S obtained a license for mining operations of the zinc-lead occurrence at Mârmorilik in the Umanak district of central West Greenland. Tailings from the flotation plant, totalling approximately 450000 tons/year, are dumped in the fjord Agfardlikavsâ (fig. 4). Understandably the local population demanded assurance that no toxic effects would harm their main source of living - fishery of prawn and fish, and prior to mining the Ministry for Greenland set stringent limits for the levels of waste products permissible.

In order to gain some knowledge of the natural background level of, in particular, heavy metals in an area so far unaffected by mining operations or industrial pollution, it was decided to investigate the natural environment before mining operations started in the autumn of 1973.

During two periods, 24th August - 1st September 1972 and in July 1973, biological samples, water samples and samples of bottom sediments were collected and subsequently analysed for $\mathrm{Pb}, \mathrm{Zn}, \mathrm{Cu}, \mathrm{Ni}, \mathrm{Hg}, \mathrm{Ag}, \mathrm{As}, \mathrm{Fe}$ and $\mathrm{Se}$ at the

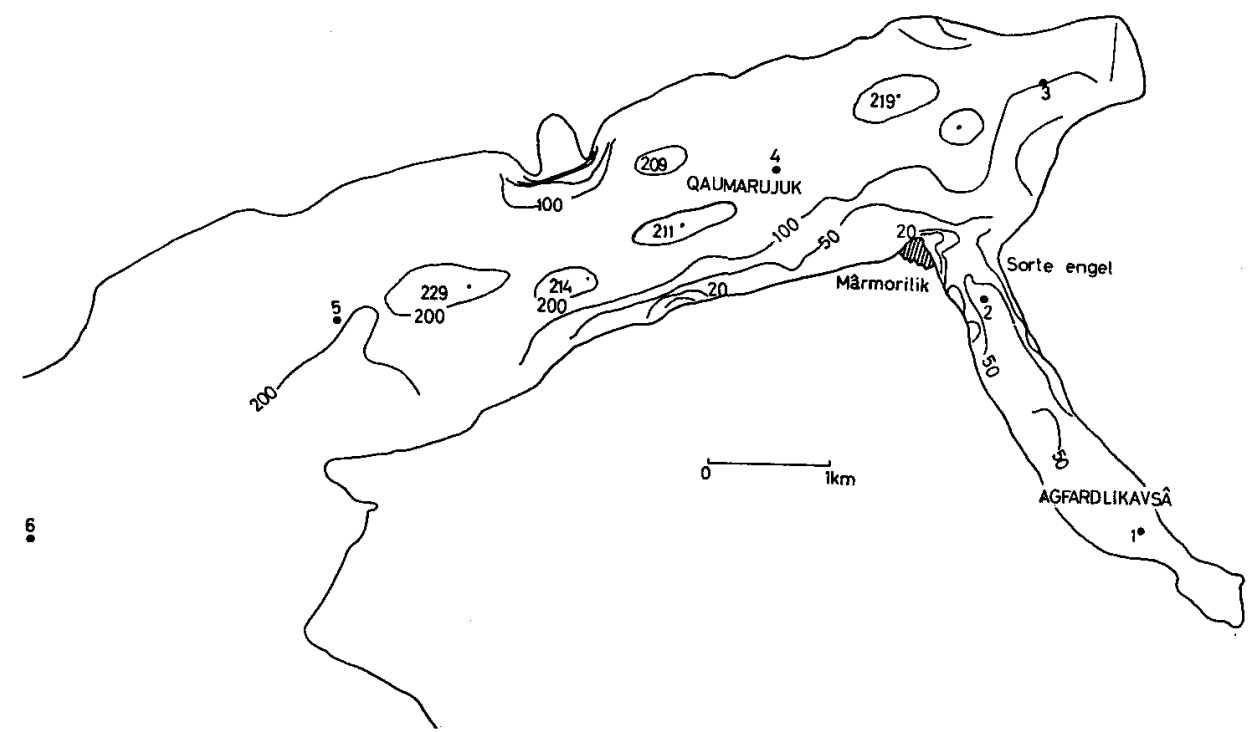

Fig. 4. The fjords Qaumarujuk and Agfardlikavsâ by Mârmorlik showing depths and sample localities. 
chemical laboratories of the Institute of Petrology, University of Copenhagen, the Geological Survey of Greenland and the Danish Isotope Centre (Isotopcentralen). Other parameters like salinity, $\mathrm{pH}$, oxygen content, turbidity and water temperature were measured in the field. In addition ecological and hydrological studies were undertaken by Vandkvalitetsinstituttet.

This short communication deals only with the main geochemical results of the whole project, in particular in relation to the bottom sediments and water samples. Full details of the analytical results are reported, in Danish, elsewhere (Vandkvalitetsinstituttet, 1972).

The study has been undertaken in cooperation with Grønlands Fiskeriundersøgelser and Vandkvalitetsinstituttet, and acknowledgement is also made to Isotopcentralen and Dansk Hydraulisk Institut for detailed studies.

\section{The bottom topography of Agfardlikavsâ and Qaumarujuk}

Agfardlikavsâ is a relatively narrow (500 m wide) branch of Qaumarujuk. Its shape is an elongated basin with a slightly sloping bottom. Water depths range from 30 to $82 \mathrm{~m}$ along its profile from south-east to north-west, and it is separated by a threshold from Qaumarujuk. The depth at the threshold is $21 \mathrm{~m}$.

Qaumarujuk is a much wider fjord $(1.8 \mathrm{~km})$, being the north-easterly extension of the main fjord in the area, Perdlerfiup kangerdlua. The bottom is generally flat with a number of minor depressions. The mean water depth is about $168 \mathrm{~m}$, while the depressions have depths varying from 204 to $231 \mathrm{~m}$ below sea level. The bottom slope of Qaumarujuk towards the west ranges from 247 to 1190 m below sea level over a distance of $7 \mathrm{~km}$, after which it merges with the main fjord.

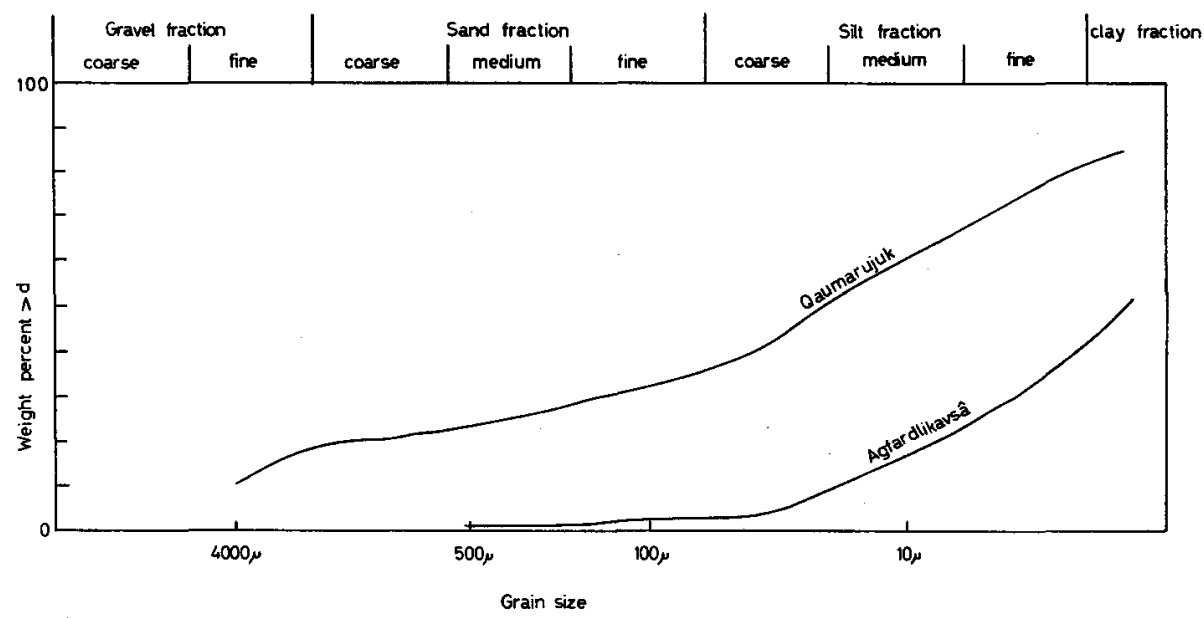

Fig. 5. Grain size of the bottom deposits in the fjords Qaumarujuk and Agfardlikavsâ. 

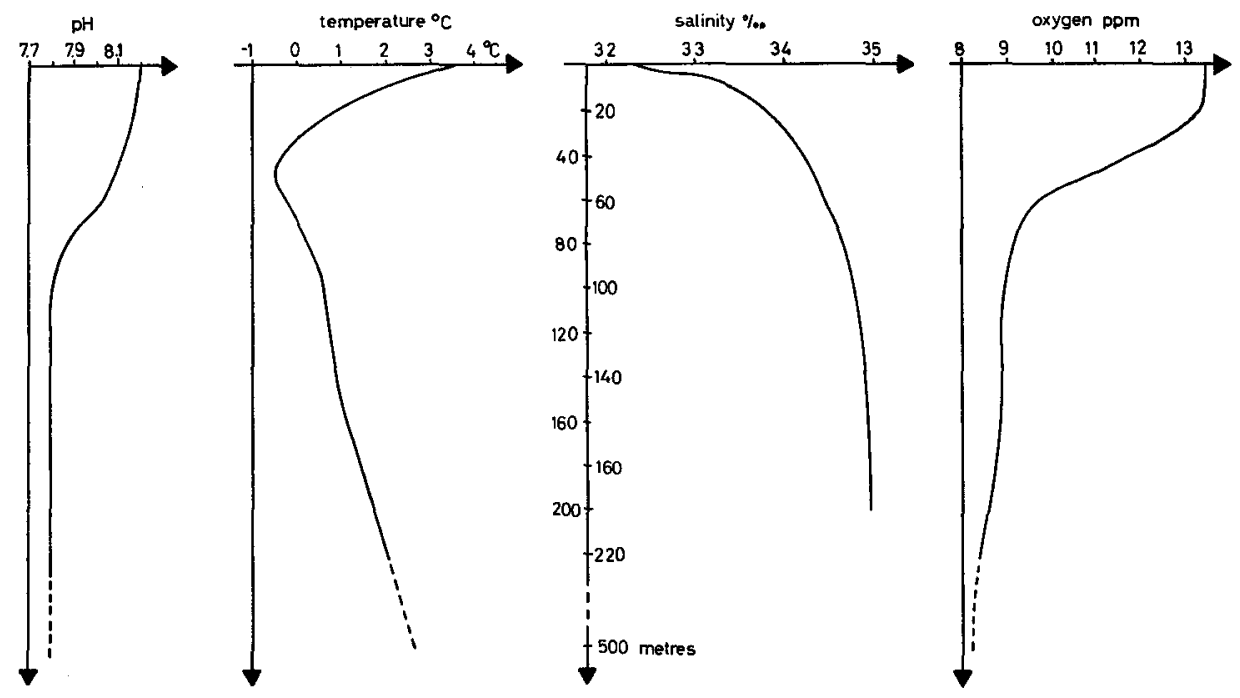

Fig. 6. Compilation of variation of $\mathrm{pH}$, temperature, salinity and oxygen content with depth in the fjord system about Mârmorilik.

\section{Bottom sediments}

Bottom sediments were sampled at 6 localities (fig. 4). Core diameter was $50 \mathrm{~mm}$, with core lengths varying from 12 to $49 \mathrm{~cm}$. Grain sizes from only one locality in Agfardlikavsâ and Qaumarujuk are given in fig. 5.

The silt-like sediments are well known from other fjords in West Greenland, pointing to low velocities along the bottom; lower than $3 \mathrm{~cm} / \mathrm{sec}$. The tidal waves have a peak to peak amplitude of $180 \mathrm{~cm}$ (spring tides) to about $90 \mathrm{~cm}$ (neap tides).

Due to marbles found in the area, the $\mathrm{CaCO}_{3}$ content of the bottom sediments is exceptionally high. Other minerals, besides calcite, are those commonly found in the surrounding granodiorites. All minerals are of primary origin; no clay minerals have been detected. This is a common feature in the West Greenland silt deposits, which mainly carry locally derived rock debris.

The high zinc content found in the bottom samples points to a local origin and low transportation rates of the bottom sediments.

The geology of the area is given on the GGU map sheet Mârmorilik 71 V. 2 S.

\section{Water samples}

Water samples were taken at a number of localities in both fjords at different depths.

Fig. 6 is a compilation of salinity, $\mathrm{pH}$, temperature and oxygen content variation with depth in the fjord system. 
Table 1. Mean concentrations of heavy metals in Agfardlikavsâ and Qaumarujuk fjords

\begin{tabular}{|c|c|c|c|c|c|c|c|c|c|c|c|c|c|}
\hline & & \multicolumn{2}{|c|}{$\mathrm{Zn}$} & \multicolumn{2}{|c|}{$\mathrm{Pb}$} & \multicolumn{2}{|c|}{$\mathrm{Cu}$} & \multirow{2}{*}{$\begin{array}{c}\mathrm{Fe} \\
\text { dis- } \\
\text { solved }\end{array}$} & \multirow{2}{*}{$\begin{array}{c}\mathrm{Ni} \\
\text { dis- } \\
\text { solved }\end{array}$} & \multirow{2}{*}{$\begin{array}{c}\mathrm{Hg} \\
\text { sus- } \\
\text { pended }\end{array}$} & \multirow{2}{*}{$\begin{array}{c}\mathrm{Ag} \\
\text { dis- } \\
\text { solved }\end{array}$} & \multirow{2}{*}{$\begin{array}{c}\text { As } \\
\text { dis- } \\
\text { solved }\end{array}$} & \multirow{2}{*}{$\begin{array}{c}\text { Se } \\
\text { sus- } \\
\text { pended }\end{array}$} \\
\hline & & $\begin{array}{c}\text { sus- } \\
\text { pended }\end{array}$ & $\begin{array}{c}\text { dis- } \\
\text { solved }\end{array}$ & $\begin{array}{c}\text { sus- } \\
\text { pended }\end{array}$ & $\begin{array}{c}\text { dis- } \\
\text { solved }\end{array}$ & $\begin{array}{c}\text { sus- } \\
\text { pended }\end{array}$ & $\begin{array}{c}\text { dis- } \\
\text { solved }\end{array}$ & & & & & & \\
\hline \multicolumn{14}{|c|}{$\overline{\text { Agfardlikavsâ }}$} \\
\hline \multirow{3}{*}{$\begin{array}{l}2 \mathrm{~m} \\
\text { depth }\end{array}$} & no. of samples & 4 & 1 & 4 & 2 & 4 & 2 & 3 & 3 & 4 & 2 & 2 & 4 \\
\hline & ave. conc. ppb & 1.0 & 77 & 4.5 & 13 & 2.0 & 71 & 3.2 & 23 & 3.0 & 0.5 & 1.4 & 2.5 \\
\hline & range $p p b$ & $0.5-1.5$ & - & $2.5-7$ & $0.5-25$ & $0.5-4$ & $7-135$ & $0-4.3$ & $0-70$ & $2.5-4$ & $0.3-0.6$ & $0.7-2.0$ & $1.5-3.5$ \\
\hline \multirow{3}{*}{$\begin{array}{l}20 \mathrm{~m} \\
\text { depth } \\
\& 5 \mathrm{~m} \\
\text { above } \\
\text { bottom }\end{array}$} & no. of samples & 8 & 7 & 8 & 8 & 8 & 8 & 8 & 8 & 8 & 8 & 5 & 8 \\
\hline & ave. conc. ppb & 1.5 & 57 & 7.0 & 19 & 3.5 & 40 & 2.6 & 13 & 4.5 & 0.6 & 1.9 & 3.0 \\
\hline & range $p p b$ & $0.5-3.5$ & $3.3-87$ & $3-16$ & $3-58$ & $1-8$ & $3-20$ & $0-5.9$ & $0-55$ & $2-10$ & $0.1-1.1$ & $0.6-3.3$ & $1-6$ \\
\hline \multicolumn{14}{|c|}{ Qaumarujuk } \\
\hline \multirow{3}{*}{$\begin{array}{l}2 \mathrm{~m} \\
\text { depth }\end{array}$} & no. of samples & 8 & 8 & 7 & 8 & 8 & 7 & 7 & 8 & 7 & 8 & 8 & 7 \\
\hline & ave. conc. ppb & 1.0 & 51 & 4.5 & 7 & 3.0 & 14 & 2.2 & 1.2 & 3 & 0.6 & 1.8 & 1.8 \\
\hline & range $p p b$ & $0-4$ & $23-91$ & $1-8$ & $1-16$ & $0-11$ & $1-35$ & $0-5.9$ & $0-4.1$ & $1-4$ & $0-1.6$ & $0.5-2.7$ & $0-4$ \\
\hline \multirow{3}{*}{$\begin{array}{l}50 \mathrm{~m} \\
\text { depth } \\
\& 5 \mathrm{~m} \\
\text { above } \\
\text { bottom }\end{array}$} & no. of samples & 15 & 13 & 15 & 15 & 14 & 16 & 15 & 16 & 15 & 16 & 14 & 15 \\
\hline & ave. conc. ppb & 1.0 & 56 & 5.0 & 6.5 & 3.5 & 12 & 2.9 & 1.5 & 3.5 & 0.8 & 1.6 & 2 \\
\hline & range $p p b$ & $0-3$ & $31-105$ & $1-14$ & $1-17$ & $1-8$ & $2-25$ & $0.3-3.7$ & $0-3.7$ & $1-9$ & $0.4-1.2$ & $0.5-2.7$ & $0-6$ \\
\hline
\end{tabular}

ppb parts per $10^{9}$ 
Chemical analyses of suspended and dissolved heavy metals are given in table 1 . Appreciable heavy metal anomalies are found in sea water adjacent to the main ore body. The impression is gained that a large volume of water is contained locally in the fjord system, since the observed concentrations are markedly higher than those found in Arctic Ocean water. According to preliminary calculations the containment period for sea water in this fjord area is less than one year. It can be mentioned that no similar anomalies in heavy metal content have been found in the fish from the area, whereas the seaweed and mussels in the immediate vicinity of the mineralisation contain abnormally high heavy metal concentrations.

\title{
References
}

Vandkvalitetsinstituttet 1972: Recipientundersøgelse for Grønlands tekniske Organisation. Undersøgelsen af Qaumarujuk Fjord, Agfardlikavsâ. August 1972. København: Vandkvalitetsinstituttet, ATV.

Geological map of Greenland 1:100 000 Mârmorilik 71 V.2 S. København: Grønlands Geologiske Undersøgelse.

\section{INVESTIGATIONS ON THE NAGSSUGTOQIDIAN BOUNDARY IN THE HOLSTEINSBORG DISTRICT, CENTRAL WEST GREENLAND}

\author{
Juan Watterson
}

This was the second season of a cooperative effort by GGU and the University of Liverpool which is aimed at determining the displacements and history of the boundary region. In addition to the writer, the following geologists participated in the mapping work: J. Grocott and D. Nash (University of Liverpool), C. Talbot (University of Dundee), and J. Diggens (Kingston Polytechnic). In addition G. Beckman and C. Morgan (Imperial College, London) carried out a palaeomagnetic sampling programme, and B. Scott (University of Edinburgh) a sampling programme on the kimberlitic dyke suite.

Transport in the field was provided by the motor-boat 'Kimberlit' and two Zodiac inflatables, with some helicopter transport provided by Diapros Canada Ltd. which is gratefully acknowledged.

The succession of events previously reported (Bridgwater et al., 1973a) requires only minor modifications but previous ideas about the relative importance of pre- and post-dyke deformations have been substantially altered. 